\title{
INDONESIAN ISLAM IN RELIGIOUS AND POLITICAL STRUGGLE DISCOURSE
}

\author{
Taufani \\ Manado State Institute of Islamic Studies
}

\begin{abstract}
This paper looks into the struggle between Islam and politics in Indonesia from Soekarno-era up to the Reform. So far, Islam in Indonesia has been known as unique because of its history. When Islam entered Indonesia, it was mystical in nature, accommodating towards local religion and culture that existed before its arrival. In the wake of the emergence of the nation-State concept in this modern age, the struggle between Islam and politics in Indonesia tends to be characterized by the presence dialectic that continues to take place, i.e. whether Islam should adopted as the sole ideology and the state positive law of the country or on the contrary where it should become the ethics and values in the spirit of the nation and State. This indicates that the struggle between Islam and politics in Indonesia is not static, but rather it tends to be dynamic and volatile as it is strongly affected by changes in the political landscape in each era of Government.
\end{abstract}

Keywords: Indonesia, Islam, Politics, Struggle and Discourse

\section{INTRODUCTION}

It is undeniable that Islam is one of the largest religions in the world today. Its adherents spread from Africa, Asia, Australia, Europe to the Americas. The growth of the Muslims "concentration camp" in numerous countries of course could not be separated from the rapid progress of globalization marked by advances in science and technology, so as to facilitate access and shorten the distance between one country and another. So far, when talking about Islam, we generally tend to think of the Middle East or the Arab world, due to the history of the arrival of Islam. However, the reality shows that the largest number of Muslims in the world is not found in the Middle East, but rather in Southeast Asia, including in Indonesia where 88.2 percent of its 235 million inhabitants is Muslim.

This article covers the issue of Islam in Indonesia. I hope this piece of writing will enrich the study of Islam in the country as there is a tendency that shows that the study of Islam in Indonesia has not been of interest to scholars because it is still often regarded as 'peripheral Islam' or 'impure Islam'. This happens because the geographic location of Indonesia is far from the heart of the 
Islamic tradition in the Arab lands. This article will describe a brief history of Islam in Indonesia and will also discuss the complexity and the dynamics of the relationship between Islam and politics in the country from Soekarnoera to the reform.

\section{THE HISTORY OF THE ARRIVAL OF ISLAM IN INDONESIA}

Talking about the history of Islam in Indonesia is not something simple, but rather quite complex as there are different versions about the history and development of early Islam. According to Sunanto (2005: 8-9) there are at least three public opinions depicting the early history of Islam in the archipelago. The first opinion argued that Islam came to Indonesia in the 7th century from Gujarat (India) as evidenced by the discovery of the first Islamic sultan's tomb, Malik al-Salih who reportedly came from Gujarat. This opinion was put forward by the Dutch orientalist scholars such as Snouck Hurgronje. A second opinion was suggested by Muslim scholars, such as Hamka and his friends who had the initiative to hold a "Seminar on the history of the arrival of Islam to Indonesia" in 1963. Hamka and his colleagues argued that Islam had existed in Indonesia around the 7th until 8th century and was brought directly from Arabia. They thought so because according to them the international sea route had been crowded before the 13th century through the Malacca Strait which connects with the Tang dynasty in East Asia, Srivijaya in Southeast Asia, and the Umayyad dynasty in Western Asia.

The third opinion was suggested by the famous historian Taufik Abdullah who tried to synthesize both of the previous opinions. According to him, Islam had indeed arrived in Indonesia in the 7th century, but was adopted by the merchants of the Middle East around the harbor. The Islamic religion entered the region and had the political power in the late 13th century marked by the establishment of Samudera Pasai. The founding of the Kingdom could not be separated from the Abbasid Dynasty collapse in Baghdad. This would later forced Muslim traders to move their trading activities to East Asia, South Asia, and Southeast Asia.

On the other hand, in that century, a lot of turmoil and warfare also took place in the Middle East, including the Crusades, so that residents in the region chose to sail to the area considered more secure, i.e. Southeast Asia. While in the area, some of them married the locals. Gradually, from this process, the Muslim communities in the area of the trade ports in the archipelago (Hadi.W.M, 2006: 446). The Mongol invasion in the Muslim lands of in other parts of the Middle East in the 13th century also 
encouraged people of the Middle East doing a massive exodus to India and Southeast Asia. The Exodus took place until the 14th century following the hectic flow of shipping and trade. Along with traders and refugees, also present were a number of sufis and their followers. The sufis later helped the spread of Islam in the archipelago.

The Malay Archipelago is one of the leading gateways, thus becoming the nearest transit point for foreign ships from the West. In addition, the ports around Malacca such as Perlak and Samudera Pasai were also frequently visited by traders. The traders lived in such places for quite a long time. At that moment, there was intermingling between traders from various nations and local people. They were introduced to the customs, culture, and religion (read: Islam). Among the traders, the Arabs, Persians and Gujaratis were generally Muslim. They introduced the Islamic religion and culture to fellow traders and local residents. The Archipelago's residents gradually embraced the religion. Islam was increasingly growing because Muslim traders also established close relations by marrying other traders and also the local people, causing the emergence of 'concentration camps' for Muslim traders in the coastal region. Since then, the local residents who had converted to Islam, and with the spirit of the religion, spread to their family and relatives, so Islam eventually grew into a popular religion.

This continued for many years until the emergence of Islamic communities that were solid, which later formed the first Islamic Kingdom in the Archipelago named Pasai with its King, Malik al-Saleh. It was the first Islamic Kingdom in Indonesia and was also the forerunner of the birth of the other Islamic kingdoms in the Archipelago. Islam became a religion that developed in Pasai at that time because Hindu-Buddhism experienced a downturn following the fall of Buddhist Kingdom which had long controlled the trade routes of Southeast Asia, namely the Kingdom of Srivijaya in the early 13th century. The setback resulted in shrinking regions the power of Srivijaya. Several small kingdoms in Sumatra that were originally controlled by Srivijaya, managed to break away such as Lamuri, Aru, Pedir, Samalangga, Samudra on the East Coast, and Barus on the West Coast. At the end of the 13th century, the Kingdom of Pasai managed to unite the various small kingdoms which broke away from the former Kingdom of Srivijaya and then sent trade envoys to China to announce its sovereignty. Finally, the Pasai came as the Kingdom that could rival the success of Srivijaya.

In the middle of $13^{\text {th }}$ century, there was a massive invasion by the Kingdom of Majapahit on Srivijaya and Pasai. The invasion severely weakened the power 
of Srivijaya, so that the authority of the Government was losing its grip. In contrast, theinvasion of Majapahitfailed to destabilizePasai. Pasaistillshowedits power as the main trader in the Strait of Malacca. Although Pasai had been defeated by Majapahit but it did not fully bring grief to Pasai, instead it brought blessings to the development of Islam in the archipelago since the prisoners of Pasai Kingdom were taken to East Java -which was the center of the Majapahit Kingdom located in Ampel Denta and Ampel Gading, Surabaya. Gradually, the place was transformed into a centre of the spread of Islam in Java and later gave birth to various walis (spreaders) of Islam. The inter-marriage between the descendants of Majapahit and Pasai was increasingly pushing more people to move to the East Java and made the Islamization process grow rapidly.

At the end of the 14th century, the last King of Sriwijaya, Paramesywara intended to restore his Kingdom and also took revenge of his defeat of Majapahit. However, Srivijaya was helpless against Majapahit. It was destroyed by Majapahit, so Paramesywara and his family, relatives, clergymen, and loyalists were forced to fled to Temasik (Singapore) and later moved to Malacca which at that time was known as a flourishing trade and transit point for travelers from different parts of the world. At the venue, Paramesywara intended to set up a new kingdom in order to restore his authority. Finally the Kingdom of Malacca then appeared to be the second Islamic kingdom in Nusantara (the Indonesian Archipelago) after Pasai. The emergence of the Kingdom of Malacca which was an Islamic Kingdom could not be separated from the help of Paramesywara who was married to the Princess of Pasai and later he converted to Islam. Rapid development of Islam in the Archipelago is inseparable from an egalitarian character. Islam knows no caste or clergy system which by religions before Islam was believed to be an intermediary tool to communicate with God. In addition, the existence of Islamic educational institutions concentrated on teaching how to write and read in order to develop an intellectual tradition also attracted the people to convert to the religion because by mastering literacy, they could raise the standard of living and social status.

After developing in the areas around the trading ports, the spreaders of Islam were increasingly expanding their mission by venturing to other coastal areas and the countryside. At this stage the traders, assisted by the sufi (wali) and supported by local authorities, played an important role in the process of Islamization. The Islamization process was relatively quick due to the selected propagation approach of Sufism. The pattern 
of sufism basically is more suitable for a society that is still heavily influenced by Hindu-Buddhist asceticism and syncretism of local belief. The pattern of Sufism also tends to be very tolerant of the practice of traditional Islamic doctrine that tends to be a little strict. The process of Islamization also spread rapidly in Indonesia because the process of spreading was not through military invasion, so that the transition from Hindu-Buddhism to Islam took place naturally without any sharp friction.

The use of art media in the spread of Islam was another attraction in the spread of Islam in the Indonesian Archipelago, so the Islamic in Indonesia is regarded as unique by many scholars. The Wali Songo (the Nine Guardians) in Java used this strategy in the spread of Islam. The 15th century Persian historian, Zainuddin Al-Ma'bari who lived quite a long time in Malabar said that many people of South India and the Indonesian Archipelago converted to Islam after hearing the stories of Prophet Muhammad that were presented in the form of poetry and songs, such as Kasidah Burdah, Syaraful Anam, Syair Rampai Maulid, especially on the birthday of the Prophet (Hadi.W.M, 2006: 454). This was exactly the medium used by the Walis in Java and other groups of Sufis in the spread of Islam, such as reading out Rawatib Shaykh Samman, Rawatib Shyekh Abdul Qadir Jaelani, etc.

With a large number of kingdoms transformed into the Islamic Kingdom, intellectual tradition characterized the Kingdoms marked by the emergence of the Muslim intellectuals, such as Hamzah Fanzuri, Samsuddin Sumatrani, Nurudin al-Raniri and Abd. Rauf Singkel in Aceh, Wali Songo in the Kingdom of Demak. Later, the Royal Palace then provided the mosque and madrasa as a centre for education and training for the da'is (Islamic proselytizers) that became the spreaders of Islam throughout the country. The proselytization was done with simple and easy to understand language, so they easily made other people interested in Islam. Starting from Pasai, and then spread to other areas in the archipelago, the Islamic Kingdoms were increasingly emerging, especially after the kings embraced the religion and was then followed by the people. In the 16th-17th century came the Kingdoms of Demak, Pajang, Mataram, Banten, Cirebon, and Madura. In the 16th century, the Kingdom of Ternate-Tidore emerged in Ambon. In the 17th century, the Kingdoms of Buton, Selayar, Gowa, Tallo in Sulawesi, Bima and Lombok in Nusa Tenggara, and Pontianak and Banjarmasin in Kalimantan. In the 18th century, in the Malay Archipelago, grew a variety of Islamic kingdoms following the decline of the Aceh Kingdom, such as Palembang, Johor, Riau, Minangkabau, etc. (Hadi W.M., 2006: 459). In later 
development, these Islamic kingdoms played an active role in the struggle to expel the invaders as inspired by the teachings of jihad which is against all forms of oppression.

\section{ISLAM IN THE ERA OF SUKARNO}

During the administration of Sukarno, there was a lot of debate about the relationship between Islam and politics. The founding fathers were engaged in a long debate about the form of the State. The debate lasted from the late 1930s until 1965. It involved the secular-nationalist groups (religionneutral nationalist) and the Islamic-nationalist circles. The secular nationalists, represented by Sukarno and consisted of the Muslims and other religious adherents, argued that nationalism should be the cornerstone and the prime mover for the people to achieve independence. Nationalism according to Sukarno is the embodiment of the sense of love on Homeland and willingness to leave the narrow interests for the sake of realizing the interests of the nation. Then, to unite the people of Indonesia in an effective manner, nationalism must be highly upheld. (Anwar: 2006; 759). The secularnationalist had the opinion that making Indonesia an Islamic State is similar to looking down on other believers and making them secondclass citizens (Madjid, 2010: 4).

The Islamic-nationalist circles represented by Ahmad Hassan, Agus Salim, and M.Natsir were not in line with the opinion of the secularnationalist and criticized the concept of Sukarno's nationalism because it was considered as a form of chauvinism and supported the spirit of tribalism ('ashabiyah), something which is strictly prohibited in Islam. They also criticized Sukarno's nationalism because it was considered a reduction of the role of religion in the public sphere. They proposed the importance of Islamic principles to guard the goals of nationalism (Anwar, 2006: 75960). However, Sukarno criticized the Islamic-nationalist back with an argument that nationalism did nothavetobeunder Islam. Heremained consistent with the separation of religion and the State and did not agree with formalism of Islam in the country. According to him, Islam should serve as a fire, spirit, soul of the state (Sukarno, 1959: 452-53).

Seeing the heat of the debate that continued to occur among the secularnationalist and the religious-nationalist ahead of independence, Sukarno did a compromise of the various ideological tendencies at that time. Sukarno then introduced Pancasila (the Five Basic Principles) that consists of the values of the divinity, humanity, nationalism, democracy, and social justice. On 5 June 1945, which is considered the day of the birth of Pancasila, 
Sukarno delivered a speech in front of BPUPKI (Governing Body of Efforts for Preparation of Indonesia's Independence ) in order to explain in detail of his ideas.

On 22 July 1945, Pancasila finally found the most perfect concept with the formulation of Indonesia's Declaration of Independence, known as the Charter of Jakarta, which later became the preamble of the 1945 Constitution. The content of the Jakarta Charter comprise (1) the Divinity, with the obligation of observing Islamic jurisprudence for the its followers; (2) a just and civilized humanity; (3) the unity of Indonesia; (4) democracy led by wisdom in deliberation of the representatives; (5) social justice for all the people of Indonesia. The Charter was signed by nine prominent figures in those days, eight of whom were Muslim, such as Sukarno, Mohammad Hatta, Abikusno Tjokrosujoso, Abdul Kahar Muzakkir,Agus Salim, Achmad Subardjo, Wahid Hasyim, Muhammad Yamin, and a Christian named A.A. Maramis. A logical consequence of the phrase 'Islamic jurisprudence' in the first principle shows that Islamic law will be observed by the State.

When Indonesia gained independence on 17 August 1945, Sukarno and Hatta declared the proclamation of the independence of Indonesia. At the moment, they did not read out the Pancasila text content. Instead, they read a new document called the text of the proclamation. The next day on August 18,1945 , when a meeting of the PPKI (Indonesia's independence Preparatory Committee) was held to formulate a Constitution, an importance issue emerged in which the Christian group that came from the North Sulawesi province wanted to break away from Indonesia if the seven words (with the obligation of observing Islamic jurisprudence for its followers) in Jakarta were not omitted.

Before removing the seven words in Jakarta, Hatta consulted in advance with two leading Islamic figures, i.e. Muhammad Hasan and Kasman Singodimejo. Hatta also had a political compromise with the Ki Bagus Hadikusumo because during that time, the latter was known as one of the prominent Islamic figures who insisted on the seven words to be included in the Jakarta Charter. After going through quite a long process, eventually the seven words were removed, with a note that the contents of the first sila (principle) of the Pancasila as set forth in the Constitution 1945 was added with the phrase «Almighty', so that it becomes "One Supreme God". The addition of the phrase 'One Supreme God' was a compensation for the abolition of the seven words and still contains substantially the quality of monotheistic (oneness of God), which is the essence of the teaching of Islam. 
The ideological debate about the form of the state had not completely ended after the political compromise that led to the omission of the seven words in the Jakarta Charter. There were still parties that were not satisfied with the replacement of the seven words. They assumed that the replacement of the first principle was another form of compromise between them and the secular group. It was then dragged the Government to establish a compromise by founding a Religious Affairs Ministry led by a Muslim, who is in charge of guaranteeing the freedom of each worshipper to observe his/her faith.

The presence of the Ministry of Religious Affairs brought discontent to the Christians because of this Ministry was regarded as another form of consciousness that implicitly said that Islam is the State religion of the Republic of Indonesia. In addition, the Department is only considered as a way to fight the State concept of Pancasila. T.B. Simatupang was a fictional character who criticized the concept of the Ministry of Religious Affairs. According to him, the Department of Religion was more suitable to be replaced with the Ministry of Religious Affairs as the term only referred to one specific religion, so Islam was the only religion that was truly cared for. Meanwhile, Department of Religious Affairs means a Department which protects and recognizes all religions in Indonesia, without placing a religion superior to others.

The Islamic-nationalist's resolve to restore the content of the Jakarta charter that failed did not stop after the independence on 18 August 1945. They still made every political effort to reinstate the Charter during a Constituent Assembly in 1959 in Jakarta. However, the secular nationalists also remained unchanged to the Jakarta Charter in which the seven words should be excluded. Each party was so consistent with its stand, so that the Constituent Assembly ran into a stalemate. Despite the voting system, it would still be difficult to give a way out because there was no party that managed to hold $3 / 4$ of the votes or $67 \%$. The Islamic groups only secured $44 \%$, whereas the Pancasila groups only $56 \%$. Upon looking at the endless debate, Sukarno finally offered a proposal to return to the 1945 Constitution. At first, the Constituent Assembly did not accept the proposal of President Sukarno, but with the help of the Armed forces of the Republic of Indonesia (ABRI), Sukarno issued the Presidential Decree on 5 July 1959. The contents of the decree are 1) the dissolving of the Constituent Assembly, 2) returning to the 1945 Constitution and to revoke the Temporary Constitution and 3) establishing the Provisional People's Consultative Assembly consisting of members of the House of Representatives plus Regional Representatives as well as the establishing the temporary Supreme Consultative Council. 
With the issuance of the Decree, Sukarno declared the birth of the period of Guided Democracy with the support of Nasakom (Nationalist, Communist, and religious group), each of which consisted of the National Party of Indonesia (PNI), the Indonesian Communist Party (PKI), and the Nahdlatul Ulama (NU). After the inception of Guided Democracy, Sukarno's leadership turned out to be authoritarian and showed no tolerance toward criticism. Sukarno's increasingly authoritarian attitude had caused the Masyumi to criticize him. However, Masyumi's criticism was regarded by Sukarno as an effort to obstruct his will. The inclusion of several Masyumi members, such as Natsir, Syarifuddin Prawinegara, and Burhanuddin Harahap into the Revolutionary Government of the Republic of Indonesia (PRRI), a rebel movement in West Sumatra in 1958, made Sukarno increasingly upset about Masyumi. Finally, in August 1960, Sukarno issued PenPres No. 200/1960 to urge the leadership of the Party to dissolve itself. Finally, on 13 September 1960 the Masyumi party was officially disbanded (Sunanto, 2005: 72).

The rebellion carried out by the PRRI and another by DI/TII in several areas in Indonesia, prompted Sukarno to take an initiative to quell the uprising with the help of the Armed Forces. After successfully crushing the PRRI and DI/TII, ABRI's popularity was increasing, so its presence was taken into account in the political scene of the country. Sukarno felt threatened, so he embraced the PKI to strengthen his political position in order to counterbalance the power of the Armed Forces because the PKI was the only force outside of the Armed Forces that had a significant political force at that time. Not long after that, in various areas in Indonesia, there was a variety of mess that was allegedly masterminded by the PKI and reached its peak in the events that killed several high-ranking officers of the Armed Forces.

The occurrence of G30S (event that killed several high-ranking officers of the Armed Forces allegedly by the PKI) then triggered the birth of outrage among the masses in various regions in Indonesia. Various elements, such as the Ansor Youth (NU), the Muhammadiyah Youth, and various other Islamic organizations, supported by the Armed Forces side by side cracked down against the PKI (Sunanto, 2005: 75). This event was the culmination of Guided Democracy in the age of ideological conflict. Sukarno's dream to establish a peaceful and dignified Government was only in dreams. In 1966, after going through a variety of crucial events, Sukarno was finally removed from Presidency. A number of high-ranking officers of the Armed Forces at the time urged Sukarno to hand over his position to the Supreme Commander of ABRI, Suharto, through the Supersemar (March 
11 Decree) for the sake of restoring social order and security (Sunanto, 2005: 76; Hefner, 2002: 388).

After the rise of Suharto as President, he put down all the things related to PKI (read: the Communists). He boycotted the whole books that had affinity with the teachings of communism. He also excommuni cated and withdrew their political rights of those related to the PKI. The entire population was forced to convert to the official religions, and as the communists were identified as atheists, most people who were adherents of belief (which is considered not religious) eventually converted to Christianity because they worried about being associated as part of the Communist (Mujiburrahman, 2001: 30).

Some Islamic circles called the 'abangan' Muslims, who had been sympathetic to the Communist Party of Indonesia (PKI), also did a massive conversion to Christianity and some to Hinduism (even though the number was insignificant). In the period from 1965 to 1971, it was reported that around2,000,000 'abangan'Muslimswerebaptized intoChristianity(Azra:2002: 213). Followers of the traditional belief and the sabangan> Muslims preferred to convert to Christianity because they were 'fed up' with various radical and barbaric actions often done by various Muslim groups against communist sympathizers after the fall of Sukarno from presidency (Hefner: 2002: 391).

The massive conversion of Muslims to Christianity also caused the two religious groups involved in tensions. According to the Boland, Islamic circles regarded Christian faith as superstitious, illogical while Christians considered the faith of the Muslims as fanatical and backward (Azra, 2002: 213). Thetensiondid notstopthere, andbothwerestillinvolved in the conflictatthe end of 1967 in which some Muslim youth group burned a number of churches in several cities, such as Ujung Pandang, Central Java, and Aceh. Christians responded by burning mosques in North Sulawesi and Ambon (Azra, 2002: 213). Such tensions eventually made the World Council of Churches in the 1974 General Assembly Council canceled the meeting in Indonesia and moved it to Africa in 1975 (Azra, 2002: 213).

\section{ISLAM IN THE ERA OF SOEHARTO (THE NEW ORDER)}

When Suharto became President of Indonesia, there was a glimmer of hope for political Islam, particularly among those who were banned during the Sukarno regime and resumed the fight for the return of Jakarta Charter to become the basis of the State. In fact, the rise of Suharto still did not bring a fresh breeze of political Islamic groups since Soeharto considered that political Islam could threaten his political policies. Islam was 
considered to be the latent danger of communism, so that after the second term, there was a pejorative at that time that said "Communism is the 'extreme left', whereas Islam is 'extreme right"' (Anwar, 2006: 766). This situation brought the relationship between political Islam and the New Order Regime (New Order) to a tension as that happened in the days of Sukarno. Although political Islamist groups had contributed to fall of communism and advocated the establishment of a new Government, the regime remained at its founding to marginalize them, as disclosed Natsir, one of the officials of the banned Masyumi who said that "the regime of the New Order treated us like ringworm cat" (McVey cited in Anwar, 2006: 767).

The tension between political Islam and Suharto during the New Order was not completely static, because in its development, Suharto still gave room to accommodate Islamic political circles, namely by agreeing to the birth of a new party named Indonesian Muslim Party (Parmusi), which was the reincarnation of Masyumi, through Presidential Decree on 30 March 1968. However, in its development, Suharto seems to half-heartedly supported the existence of this party, which was indicated by his rejection of the amalgamation of the senior figures of the Masyumi into the party. To realize his vision, Suharto intervened in the cancellation of the election of Mohammad Roem, a senior figure of Masyumi who was to become Chairman of the Parmusi and then offered another alternative figure considered more cooperative as a step to control the party. This event caused a massive split within the Parmusi (Hwang, 2011: 72).

The intervention of the New Order regime on the Parmusi resulted in the decrease of the party's vote tally in the 1971 elections, in which it only gained $5.4 \%$ votes, far below the result gained by the Masyumi in 1955 elections that managed to garner 20.9 percent of the votes. Although the overall votes of the Islamic parties were merged (27.2\%), they still could not beat the Golkar which was Suharto's main supporter that managed to reach $62.8 \%$ of the votes. Despite the fact the combined vote tally showed that the Islamic party was still far below the Golkar, the New Order regime still considered presence of Islamic parties as a threat to Suharto's political policies. Therefore, for the sake of restricting the growth of Islamic parties, the New Order regime implemented a two spearhead strategy, which supported personal piety and Islamic cultural movement on one hand but on the other hand, opposed to the presence of political Islam in any form of politics.

To delegitimize and depoliticize political Islam in Indonesia, in 1971, the New Order regime decided to merge political party system. The fusion seccessfully dispersed all Islamic parties (Parmusi, NU, PSII, and Perti), 
which represented a relatively distinct ideology, under the flag of the United Development Party (PPP), and the secular-nationalist and Christian parties under the Indonesian Democratic Party (PDI). In addition, the New Order regime also confirmed to the parties that the it had the right to intervene in the election the party leadership as well as the formulation of party policy, so that their presence would not bring a threat to Golkar that became Suharto's political vehicle (Hefner, 2002: 395). Other forms of intervention against political parties, according to Hwang was banning any party to open a branch in villages or hamlets, banning any party doing demonstrations or recruitment of cadres one month before the elections, banning the party from campaigning outside the campaign period, and did not allow the competent cadres of political parties to hold the office of governor, mayor, and head of the village, except for Golkar cadres (Hwang, 2011:73-74). On the contrary, with more power that justified all means, the New Order, in order to maintain control commanded the entire civil servants to swear allegiance to and vote for Golkar in elections, because Golkar was considered the only state representation.

Ahead of the elections in 1977, the New Order regime played a political intrigue by using character assassination strategy against its rivals. The New Order accused the PPP as part of a group of secret radical Islamist called the Komando Jihad which intended to overthrow the Government. In addition, the regime also conducted numerous practices of intimidation, coercion, and restrictions on political parties that were considered to be a rival of Golkar. However, it did not entirely succeed because Golkar remained unable to decrease the PPP vote tally drastically. So, in the 1977 elections, the PPP was still able to collect significant votes of $29.29 \%$. The delegitimization efforts against political Islam did not just stop there, ahead of the general elections of 1982, the New Order regime issued a controversial policy, which set Pancasila as the sole basis for all political parties. As a result, each political party was required to abandon its ideology and replaced it with the Pancasila.

PPP was one of the victims of the single basis of assignment. The PPP was forced to abandon the party's ideological line of Islam because of the policies of the new order regime requires that the entire parties in the country should refer to a single principle. The symbol of the Kaaba in the PPP `s identity must also be converted into the sign of stars, which was one of the symbols in the Pancasila, because the new order also prohibited the use of Islamic symbols as a symbol of the party. The use of Pancasila as the sole basis was not only imposed on political parties, but also applied to civic organizations. One 
of the organizations affected by the outbreak of the application of the sole principle was the Association of Islamic Students (HMI). Consequently, the HMI split into two groups in which HMI DIPO accepted a single basis policy, and HMI-MPO chose to maintain the Islamic identity in its statute secretly.

Essentially, the principle of Pancasila as the sole designation received a lot of criticism from Muslims because they assumed that Pancasila was created by humans so that it cannot be paralleled with the Quran which is the creation of God. However, the regime of New Order anticipated the opposition by banning and considering the whole discussion related to SARA (ethnicity, religion, race, and inter-group relations) in order to create the monoloyalty to Pancasila. To that end, the New Order regime never hesitated to take hard measures against those who resisted the Pancasila and broke the taboos about SARA. Many Muslim activists were arrested and jailed because they rejected the policies applied by the regime.

Based on the above facts, it can be said that the relationship between the Muslims and Suharto in the era of the 70 s to the early ' 80 s was less harmonious. However it cannot be forgotten that the Suharto era saw the golden age of Muslim intellectuals whose background was santri (student of Islamic boarding school). These Muslim intellectuals studied not only the 'yellow books' (religious books), but also the 'white books' that come from the Western tradition of science such as sociology, anthropology, philology, etc. Armed with multi-disciplinary sciences, the Muslim intellectuals with santri background resumed the idea of an Islamic State that once championed by the Muslim generations before them. For them, the fight for social justice concerning the substance of Islam and Islamic ethics cultivation in the life of nation and State was much more important than merely a fight for Islam as a flag or symbol.

One of the prominent Muslim intellectuals at the time was Nurcholish Madjid (Cak Nur). Cak Nur was among the golden generation of Muslims in his days who not only mastered the corpus of classical Islam, but was also knowledgeable about the tradition of Western thought. It was from the traditions of Western thought that Cak Nur learned about the ideas of democracy, pluralism, and human rights, and synthesize them with the teachings of Islam which is universal in nature. One of famous theses by Cak Nur was "Islam, Yes, Islamic party, No." When the thesis was put forward by CakNur, Islamist parties were almost aligned with the religion of Islam itself, so Muslims should support Islamic parties. According to Cak Nur, it is irrational because in other parties, there are also Muslims. As an intellectual, Cak Nur felt compelled to explain to the people that Islam is 
not an exclusive religion, rather it is inclusive and capable of adapting to a variety of situations and conditions. According to him, the fight for Islam does not have to be through a political party, but there are still many other ways to do it, one of them by upholding social justice in everyday life.

The thesis put forward by Cak Nur was also born as a form of his concern over the weakness within society of the Muslims, so they are getting left behind by the times. According to Cak Nur, Muslims are left behind because they are too busy thinking of things that lack of principle in religion, otherwise things that could bring the benefit tend to be ignored. He exemplified the idea of the establishing an Islamic State championed by the Islamic parties is no longer popular, because there has been a gap between expectations and reality. According to him, the Islamic party cadres who have been championing the idea of an Islamic State have failed' to show sympathy and positive image in the community because some of those involved in corruption scandal (Madjid, 2008: 226-27). He offered an alternative that emphasizes the need for openness, freedom, progressiveness and creativity in thinking that is embodied in the concept of secularization, the idea of progress, and intellectual freedom, so that Muslims could meet the coming era of modernization that requires rationality. Cak Nur said that secularization is not intended as an application of secularism and turns the Muslims to be secularists, but it is meant to appreciate the values that should be worldly, and set the Muslims free from a tendency to orient themselves to the hereafter. Thus, the mental willingness to always examine the truth of a value should be among the characteristics of Muslims. Further, secularization is meant for fulfilling the task of human being a "Caliph of God on Earth». The function as a Caliph of God certainly should give room for the existence of human freedom to set and choose their own ways and actions in order to repair their life on Earth and provide a justification for the existence of human responsibility for the deeds before God (Madjid, 2008: 229-30).

Cak Nur further says that,

... the idea of progress is an open mental attitude, willingness to accept and learn the values (worldly) from anywhere, as long as they contain the truth. So, in line with the intellectual freedom, we must be willing to listen to ideas of development of humanity to the highest possibility, and then choose which one according to the objectives that contain the truth. It is difficult to understand that Muslims are not open in their attitude, whereas the Holly Book affirms that they «must listen to ideas and follow the best"(Madjid: 2008: 234).

In addition to the Cak Nur, other intellectual Muslims with santri background 
that took part in reforming Islamic thought in the 70s and 80s was Abdurrahman Wahid. Wahid was known as the grandson of the founder of Indonesia's largest Muslim organization, the Nahdlatul Ulama (NU) Hasyim Ashari, one of his works was the reform of Islam in Indonesia is helping to introduce the contemporary ideas, such as democracy, pluralism, and human rights in within the NU, including in the pesantren (Islamic Boarding School) which was the base for the movement of NU. The NU is often regarded as a conservative and traditional Islamic organizations. The openness displayed by the NU in adopting such contemporary ideas received complements from CakNur as the movement has shifted from traditional to modern.

When many Muslims have yet to approve a single principle of Pancasila, Wahid andK.H. Ahmad Siddiq in the NU Congress in 1984 decided to take a progressive step to accept Pancasila as the sole basis. Despite accepting Pancasila as the sole basis, Wahid chose not to bow to those in power. Instead, he appeared as a critic of Suharto's authoritarianism. Meanwhile, in Wahid's perspective, Pancasila is not a closed ideology as practiced by the New Order regime. The Pancasila however is a principle which contains universal ethical values and capable of accommodating and bridging existing pluralism in Indonesia. In short, in the hands of Wahid, the NU organization quickly transformed into a modern organization that is now widely known among the international community.

In addition to the CakNurand Wahid, in fact there were more prominent Muslim intellectuals who contributed to renewing Islamic thought in that era, in the frameworkof themodernization efforts of proclaimed by the NewOrder. Among them were Harun Nasution, M. Dawam Rahardjo, Djohan Effendi, Adi Sasono, Mansour Fakih, etc. (Azra, 1999: 52-53).

Towards the end of the 80s and early 90s, the political landscape in Indonesia was experiencing a considerable shift, characterized by Suharto's good relations with Islamic organizations. Soeharto had no choice because he realized that his power was getting increasingly weaker after several military elites left him. They left Suharto because they were not pleased to see the growing concentration of wealth in the family of Suharto's circle. According to Hefner (2002: 395), an effort made by the regime to appease Muslims also could not be separated from the awareness of the Presidentss advisers that saw the rapid rise of Islam in many Muslim lands, such as what happened in Algeria. They were aware that it was time that the government took into account and accommodated Muslims in power if Soeharto wanted to to survive.

By the early 90s, Suharto finally issued a variety of partial policies in 
order to accommodate the interests of Muslims, such as the establishment of Islamic banks, construction of mosques, expansion of Islamic courts, issuance of the regulation on the national education system, support for the holding of a National Islamic festival, legalization of the use of headscarves for female students in schools, and also supports the establishment of Indonesian Muslim Intellectuals (ICMI).

\section{ISLAM IN THE REFORM ERA}

After the fall of Soeharto from the Presidency in May 1998, a hope that new politicalwind would blowinto this countrybegan to emerge. In line with the spirit of reform that demanded political freedom and openness, Habibie allowed the establishment of new political parties, new media, new organizations, and various other institutions to strengthen the power of civil society. The policy was well received by the people indicated by the high enthusiasm to found new political parties in order to channel their political aspirations and to participate in policy formulation in the future. Ahead of the 1999 elections, there were 48 new parties that took part in the elections, including several Islamic parties.

In the early era of the Reform, the Islamic parties again demonstrated their passion to fight for the implementation of the Jakarta Charter and the implementation of Islamic jurisprudence law as an alternative to the positive law in the country. Therefore, they took advantage of the momentum of the economic crisis at that time to offer Islamic solutions. During the campaign of the elections in 1999, several Islamic parties, such as the United Development Party (PPP), Justice Party (PK), and the Crescent Star Party (PBB), appeared with the agenda of applying Sharia law in Indonesia. Unfortunately, however, the dream of an Islamic party to apply Islamic jurisprudence remained a dream because the votes garnered by the Islamic parties in 1999 elections reached only $17.8 \%$, making them difficult to insist on the implementation of the Jakarta Charter in the amendment of the Constitution in the MPR General session in 2000.

In addition to the emergence of various Islamic parties, the Habibie was era also marked by various 'radical' Islamic organizations such as Mujahideen Council, Hizbut Tahrir, Islamic Law Enforcement Committee (KPSI), etc. which aimed to fight for the establishment of an Islamic State in Indonesia. These organizations were heavily influenced by Middle Eastern Islamic militancy paradigm (Nasir, 2007: 269). Despite the struggle of the enactment of the Jakarta Charter first championed by the Islamic political parties were deadlocked as a result of less significant votes they received in the 
Parliament, it did not change the determination of 'radical' Islamic activists to fight for their political aspiration. With the support of epistemic strength of the community, making them strong and solid in the regional level, they discreetly fight for their big dream of establishing an Islamic State. After going through a long struggle, the 'radical' Islamic activists ultimately succeeded in reaching their goal in the form of the application of Islamic Sharia law in some areas in Indonesia, such as in Bulukumba, Aceh, Banten, etc.

After Abdurrahman Wahid was elected as the new President to replace Habibie, new hope began to emerge especially with regard to Wahid's leadership style widely-known as a progressive and democratic figure. Unfortunately, Wahid's leadership was marked by bloody communal conflicts happening in the name of religion, i.e. Islam-Christians, such as those in Poso and Ambon, Ternate. To cope with the communal conflict, Wahid tried to hold peaceful dialog to offer a solution by calling the two parties in conflict, i.e. Laskar Jihad and Laskar Kristus. However, peaceful dialog solution offered was not effective. The Laskar Jihad through its leader, Jafar Umar Thalib kept sending its members to Ambon to fight Christians because Talib claimed that its action is justified by the Sharia. Talib did not heed dialog solutions offered by Wahid, instead he criticized Wahid as his policies were considered unclear regarding how to end the massacres of Muslims in the Maluku.

Wahid's tenure was also marked by a variety of radical actions, such as that conducted by the Islamic Defenders Front (FPI). The presence of FPI in Indonesia was a response to the increasing moral decadence following a pattern of a hedonist lifestyle and permissive towards sinful practice. The FPI emerged to the surface and positioned itself as a 'moral police' who is in charge of conducting raids to destroy nightspots, places that provide alcohol, gambling and prostitution, and hotels that hide unlawful practices. The members of the FPI also rallied to take to the streets to fight for their aspirations to uphold Islamic jurisprudence and urged people to eradicate immoral attitudes.

After his impeachment by Parliament, Wahid`s position as President was replaced by Megawati, who was Vice President at that time. One of the issues when Megawati served as President was the rejection by some Islamic groups against her because according to textual interpretation of Sharia law, women are not allowed to become the leader of a country. However, Megawati was not discouraged from running her duties as the head of State. The issue of the leadership of women slowly faded upon the presence of Hasyim Muzadi who was the Chairman of the Governing Board of the Nahdlatul Ulama and also one 
of the elite scholars of the National Awakening Party (PKB) as Megawati's prospective vice president in the 2004 election. However, Megawati's lost to Susilo Bambang Yudhoyono (SBY) and Jusuf Kalla (JK) in the general election because of the support votes from members of the NU were split after the candidacy of Salahuddin Wahid (younger brother of Wabduraahman Wahid and was also an elite cleric of the PKB who ran for vice president along with Wiranto, and thus favoring the stronghold of SBY-JK.

SBY's leadership era was marked by the growing radical actions by Islamic groups. This resulted in the increasing act of destruction of houses of worship and also physical violence against minorities, as experienced by the Ahmadiyah and Shi>ah. Many observers assumed that the weak characters of SBY's leadership somehow contributed to those incidents, although he came from a military background. Yudhoyono's era was also marked by the growth of radical action carried out by the Islamic movement. Among the various Islamic organizations, the FPI was the one that most frequently drew the attention of the public because in upholding the values they observe, the FPI justified vandalism, such as sweeping and damaging facilities of bars, discotheques, where localization and various other night entertainment venues, especially during the month of Ramadan. The FPI also often conducted sweeping on the restaurants open during the day such as the incident of Coto Makassar in 2011.

In order to enforce their version of Islamic understanding, the members of the FPI also halted a wide range of activities that are considered as 'harassing' Islam as they did in 2005 by attacking the Drag Queen show held at the Sarinah Hotel and dismissed the event of the transgender at the Bumi Wiyata Hotel in Depok in 2010. They did not stop there. The members of the FPI also damaged the Government-owned offices in 2012 due to the cancellation of legislation on alcoholic drink. In short, the struggle of Islam in the Reform era has been generally marked by the growing radicalism under the name of religion (Islam).

\section{CONCLUSION}

Islam that was brought to Indonesia is unique since its spread patterns tend to lean towards Sufic approach so it can adapt easily to the socio-cultural condition of the community. Very few incidents were found in the process of Islamization in Indonesia. On the contrary, the process of Islamisation of Hinduism-Buddhism to Islam tended to be natural. In fact, among the scholars there is still a debate going on the time of the coming of Islam to the archipelago. However, in general, the process of Islamization developed 
during the reign of the King of Pasai in Aceh who converted to Islam. After that, Islam later spread to different wider regions of the archipelago, such as Java, Sulawesi, Maluku, etc. When Islam has become the religion of the majority, the colonizers assumed that Muslims were a real threat to their existenc e in Indonesia. In colonial times, Muslims were highly respected by the coloni zers. The invaders were aware of the strength of Islam because its followers had a strong solidarity, in addition to its teaching that teaches a revolutionary and anti-oppression through the doctrine of jihad.

After the independence of Indonesia, the relationship between Islam and the State tended to be dynamic. This happened because the founding fathers tended to have a different interpretation on the meaning of the relationship between Islam and the State. Among the secular nationalists (religious neutral nationalists) who agreed with the doctrine of the separation between religion and State considered that the establishment of an Islamic State in Indonesia was no longer needed. The most important was to implement Islamic values and ethics as a spirit in the country. In other words, the secular-nationalist circles were more likely to see Islam from the perspective of a more substantialist view. In contrast, the religious-nationalist assumed that an Islamic State is a country that formally makes Islam the basis of the State and also as an alternative to formal legality against various other systems. The religious-nationalist circles in this case tended to be more formal. Although a bit allergic to political Islam, the State has never constrained the Muslims to practice the ibadah (worship) Islam (a term coined by Kuntowijoyo) or ritual Islam.

In the era of Suharto, the relationship between Islam and the State was similar to the time of Sukarno. In the early days of Suharto 's rule, Islam was considered to be a threat, thus came the pejorative term «extreme rights. However, the tensions between Islam and the State did not take place in a static but rather in a dynamic way. In the late 80 s, a period in which Suharto's power weakened, especially after he was abandoned by the military elites that stood behind him, he finally issued a variety of partial and controversial policies in order to accommodate the interests of the Muslims that had significant influence to secure his power.

During the time of the Reform, in the wake of Suhartors fall, the political landscape in Indonesia turned out to be more democratic, characterized by the existence of freedom of speech, opinion, and association. However, the sad thing is that freedom resulted from the Reform has sometimes been articulated negatively in the form of radical actions on behalf of religion (Islam). This, as a result, changed the image of Indonesian Islam from friendly Islam to angry Islam. 


\section{REFERENCES}

Anwar, M.Syafi'i. 2006. "Gerakan Muslim Modernis: Pergumulan Wacana dan Politik Pasca Orde-Baru", dalam Komaruddin Hidayat dan Ahmad Gaus AF (eds). Menjadi Indonesia: 13 Abad Eksistensi Islam di Bumi Nusantara. Jakarta: Mizan dan Yayasan festival Istiqlal.

Azra, Azyumardi. 1999. Konteks Berteologi di Indonesia: Pengalaman Islam. Jakarta: Paramadina.

. 2002. Reposisi Hubungan Agama dan Negara: Merajut Kerukunan Antarumat. Jakarta: Kompas.

Hadi. W.M, Abdul. 2006. "Islam di Indonesia dan Transformasi Budaya", dalam Komaruddin Hidayat dan Ahmad Gaus AF (eds.). Menjadi Indonesia: 13 Abad Eksistensi Islam di Bumi Nusantara. Jakarta: Mizan dan Yayasan festival Istiqlal.

Hefner, Robert W. 2002. "Keadaban Demokrasi: Refleksi tentang Beberapa Prasyarat bagi terwujudnya Civil Society di Indonesia", dalam Munim A. Sirry (ed.). Islam, Liberalisme, Demokrasi: Membangun Sinerji Wawasan Sejarah, Doktrin, dan Konteks Global. Jakarta: Paramadina.

Hwang, Julie Chernov. 2011. Umat Bergerak: Mobilisasi damai Kaum Islamis di Indonesia, Malaysia, dan Turki. Jakarta: Freedom Institute.

Madjid, Nurcholish. 2008. Islam, Kemodernan, dan Keindonesiaan. Bandung: Mizan.

Madjid. Nurcholish. 2010. Islam Agama Kemanusiaan: Membangun Tradisi dan Visi Baru Islam Indonesia. Jakarta: Dian Rakyat-Paramadina.

Mujiburrahman. 2001. "Religious Conversion in Indonesia: the Karo Batak and the Tengger Javanese" dalam Islam and Christian-Muslim Relations, Vol. 12, No. 1, January 2001. h.23-38.

Nashir, Haedar. 2007. Gerakan Islam Syariat: Reproduksi Salafiyah Ideologis di Indonesia. Jakarta: Pusat Studi Agama dan Peradaban (PSAP) Muhammadiyah.

Soekarno. 1959. Di Bawah Bendera Revolusi. Djilid I. Djakarta: Panitya Penerbit di bawah Bendera Revolusi.

Sunanto, Musyrifah. 2005. Sejarah Peradaban Islam di Indonesia. Jakarta: PT. RajaGrasindo Persada. 